\title{
Exploration on Teaching Reform of Material Mechanics Course Based on Ideological and Political Cultivation
}

\author{
Ruiying Shao \\ Qingdao Huanghai University \\ Qingdao, China \\ 93659949@qq.com \\ Juan Song \\ Qingdao Huanghai University \\ Qingdao, China
}

\author{
Hongjun Wang \\ Qingdao Wanbao Compressor Co., Ltd. \\ Qingdao, China
}

Weiwei Ge

Qingdao Huanghai University

Qingdao, China

\begin{abstract}
In order to realize the need of cultivating people in all aspects, this paper mainly strengthens teachers' moral education, and integrates ideological and political education in the aspects of teaching content, teaching methods and assessment methods on material mechanics courses to strengthen students' ideological and political education, guide students to learn independently and enhance their interest and participation in learning. Thus it can improve the teaching quality and cultivate the engineering application talents with high quality and innovative.
\end{abstract}

Keywords-ideological and political training; material mechanics; teaching reform

\section{INTRODUCTION}

The course of material mechanics is an important technical basic course for cultivating students with more skilled computational ability, certain analytical ability and experimental ability in mechanics. Material mechanics is a follow-up mechanics course of theoretical mechanics. It is a course of mechanical design and manufacturing. The main course of automation undergraduate major is also a professional foundation course in vehicle engineering, ship and ocean engineering ${ }^{[1]}$. The course of material mechanics not only teaches students the basic knowledge of the profession, but also cultivates students' innovate ability, teamwork and patriotism.Specialized course teachers should change their educational thoughts and teaching concepts, and explore the ideological and political education materials in the teaching content carefully, and combine the curriculum ideological and political content with the professional course teaching, and improve the teaching quality of the material mechanics course.

\section{Problems In the TEACHING OF MATERIAl MeChaniCs AT THE PRESENT STAGE}

At this stage, most of material the mechanics content are relatively old and the teaching method is relatively simple, which is not conducive to stimulating students' sense of innovation. The content with high theoretically, so the students learn it boring, less creating and thus losing their enthusiasm for learning. Most teacher work in school after graduation, so they lack engineering practice experience. In the process of teaching material mechanics, there are still fewer content of ideological and political education. Based on the above problems, it is urgent to reform the teaching methods, teaching contents and assessment forms of Material Mechanics, and improve the teaching quality,and cultivate students' mechanical quality and innovative spirit.

\section{III. "MATERIAL MECHANICS" BASED ON IDEOLOGICAL AND POLITICAL TRAINING" REFORM MEASURES}

The course of material mechanics teaching not only teaches students the basic knowledge of the profession, but also cultivates students' innovate ability, teamwork and patriotism. Professional teachers should change their educational thoughts and teaching concepts, and explore the ideological and political education materials in the teaching content carefully, and combine the curriculum ideological and political content with the professional course teaching, and improve the teaching quality of the material mechanics course. This article will teach in the following four aspects.

\section{A. Strengthen teachers' moral education}

Due to the different levels of enrollment of students in private undergraduate colleges and universities, as a private college teachers need to improve their ideological and political level to do a good job in ideological and political education for students. You can learn from the following four aspects:

Party Building Project in the Construction of the Benchmarking Institute of the Intelligent Manufacturing Institute of Qingdao Huanghai College:

Construction Project of the Course Mechanics 
certain political foresight and flexibility and the corresponding ideological and theoretical cultivation and speculative ability, finding the combination of professional and ideological and political courses, and integrating professional education with ideological and political education. Meanwhile it needs the teachers who can plan and organize orientation education timely and effectively, and solve the major theoretical and practical problems in the process of students learning and life and reform and opening up and modernization construction.The teachers need to make it deep, thin and firm.

\section{Changing teaching methods and integrate into ideological and political education}

1) Reforming educational methods and strengthening curriculum moral education

Previously,according to the requirements of the syllabus and less integrated with ideological and political education, the students felt the course theory was very hard and lacked the interesting. It was difficult for students to learn, and teachers were more difficult to teach. In the future teaching, combining professional knowledge education with ideological and political theory education can not only enable students to easily learn professional knowledge, but also cultivate students' patriotism and innovation ability. In the process of teaching this course, teachers use the masters thought and academic masters in this discipline to influence and infect students, thus subtly educating students on ideological and political education. For example, when introducing theoretical knowledge in the teaching process, by introducing the academic achievements of these masters, teacher's personality charm affects students. The research task of material mechanics is to cite two ancient buildings. One was the 63.4-meter long bridge in Hebei Province, built in the Sui Dynasty (605 years), with a span of 37.02 meters and a stone of 2,800 tons. It is the oldest arch bridge. The second was built in the Liao Dynasty (1056). The 9th floor of the Shah Tata Tower in the Ying County of Shanxi Province was 67.31 meters high. It used 7,400 tons of wood. After several years of earthquakes in 900 years, it was the only existing wooden tower. Let students feel the wisdom and pride of ancient Chinese, and enhance their pride and patriotism.

\section{2) Carrying out practical activities of enterprise}

In the process of teaching, we must adhere to corporate collaborative education, and carry out enterprise-based campus practice activities such as skill competition, quality development, and mock interviews ${ }^{[4]}$, and integrate knowledge and education with professional practice. And use the favorable conditions to provide students to contact the actual project, and guide the students to combine the theoretical knowledge to point out the actual mechanics problems appearing in the project, and help the students to better understand the basic theoretical knowledge, and stimulate students' interest in learning, and form engineering awareness gradually.

In practice teaching, we must pay attention to cultivate the school's innovate ability and teamwork. We can adopt a structure, such as compulsory items and limited items and optional items, and choose the practical projects according to the students' own characteristics. Then, in the class, the group leader is freely to be determined. Each group formulates specific plans according to the teaching requirements and 
and political education, and form the synergy of online and offline ideological and political education ${ }^{5]}$.

the practice links. In practice teaching inspection PPT can be used to report the results of its own group. In order to prevent some students from coping with it, the reporting personnel are randomly selected in each group, and the teachers and students' questions are answered after the report. All the students need to participate in the whole process, to develop students' teamwork ability, language expression ability, innovation ability and enhance the sense of collective honor.

\section{3) Using analogy}

Students are generally interested in things in life, comparing mechanics with life examples, and students are easy to understand and remember. For example, when teaching the ultimate stress, allowable stress and safety factor, an example can be given: the maximum load capacity of a bed is $300 \mathrm{~kg}$, beyond $300 \mathrm{~kg}$, the bed is crushed, and $300 \mathrm{~kg}$ is compared. It is the ultimate stress. In order to make the bed more safe, it is stipulated that its allowable bearing capacity is $250 \mathrm{~kg}, 250 \mathrm{~kg}$ is used as the allowable stress, $n$ is the safety factor, and the three parameters have the following relationship:

$$
\sigma=\frac{\sigma^{0}}{\mathrm{n}} \leq[\sigma]
$$

If $\mathrm{n}=1, \sigma=300 \mathrm{~kg}>[\sigma]=250 \mathrm{~kg}$, this bed is not safe; if $\mathrm{n}=1.5, \sigma=200 \mathrm{~kg}<[\sigma]=250 \mathrm{~kg}$, this bed is safe and can sleep one Adult; if $\mathrm{n}=3, \sigma=100 \mathrm{~kg}<[\sigma]=250 \mathrm{~kg}$, this bed is safer and can sleep a child; in turn, the larger the analogy, the safer it is, so it is called the safety factor. It is not the bigger, the better; this bed could have slept a big person. If $\mathrm{n}$ is too big to become sleep a child, it will also waste materials, so it is necessary to consider not only the safety but also the economic conditions. This kind of analogy is easy for students to understand. Through the analogy method, students can deeply understand the relationship between the ultimate stress and the allowable stress and the safety factor when designing the engineering structure, which enhances the sense of responsibility and mission in design.

\section{4) Strengthening ideological and political education with} online courses

In teaching methods, make full use of the advantages of multimedia in teaching. In teaching organizations, it is not enough to rely solely on the "blackboard + chalk" teaching mode. Teachers can express concepts, theorems, formulas, etc., but it is impossible to present complex engineering problems and various institutions. Therefore, through the multimedia expression, more actual engineering cases are displayed, and the images are vivid. With the help of the online course of material mechanics network, we can answer students' learning and life problems in a timely manner, pay attention to the students' ideological dynamics in a timely manner, actively guide and educate, expand the channels of students' ideological

\section{Reforming the form of assessment, and the ideological and political education runs through it.}

1)In the past, only the closed-end examination was conducted in the form of closed-books. The practice links of the students were not assessed, and the students' practical ability could not be measured. Now, using the combination of final exams, experiments and procedural assessments, the ideological and political education is carried through the entire assessment process. Through the writing of small papers and group reports, the students' behavioral ethics and peacetime learning process will be enhanced and the students' enthusiasm for learning will be mobilized.

2) Encourage the exchange of course credits in academic competitions to cultivate students' innovative spirit and innovative consciousness. In order to cultivate college students' sense of innovation, improve their ability to innovate, and help college students to innovate and start businesses, students are encouraged to participate in mechanical and electrical products and new energy innovation and entrepreneurship competitions.

\section{CONCLUSION}

By strengthening teachers' moral education, reforming teaching content and links, changing teaching methods, and reforming assessment forms, the ideological and political education is integrated into the teaching process of material mechanics, which changes the originally boring classroom and mobilizes students' active learning. A significant improvement. As a teacher of a private undergraduate college, it is necessary to let $100 \%$ of the students participate in the classroom. The task is a long way to go, so continue to strengthen the teaching reform for ideological and political education.

\section{REFERENCES}

[1] Sun Yuhua. Exploring the implementation of CDIO concept in the teaching reform of Material Mechanics course [J]Science and technology.2017.6

[2] Li Huaguang, An Feifei. Teaching Reform and Exploration of Ideological and Political Education in the Course of Electrotechnics[J]Science and technology.2019.17

[3] Duan Jun, Ban Yuxin, etc. Research and discussion on material mechanics curriculum reform based on applied talent training [J]. Course Education Research. 2015.24

[4] Wu Hongying. Innovative Exploration of Practical Teaching Mechanism of Ideological and Political Theory Courses in Higher Vocational Colleges [J] School Party Construction and Ideological Education. 2016.2

[5] Ren Yonghui. Reflections on the integration of ideological and political courses and professional courses in higher vocational colleges [J] Occupation.2015.3 